\title{
THREE WEDDINGS AND A DIVORCE: GOD'S COVENANT WITH ISRAEL, JUDAH AND THE CHURCH
}

\author{
David Instone Brewer
}

\begin{abstract}
Summary
God is described in the Old Testament as married to Israel and Judah, and in the New Testament the church is described as the Bride of Christ. The marriage to Israel ended in divorce and the marriage to Judah suffered a period of separation. Paul suggests that this marriage ended when Christ died, in order that Christ would be free to marry the Church with a better marriage covenant. These marriage covenants are detailed by several authors in the Old and New Testaments. These several accounts are consistent with each other and demonstrate that God subjects himself to his own law in the matter of marriage and divorce.
\end{abstract}

\section{Introduction}

Several authors throughout both the Old and New Testaments make mention of marriage covenants which God contracted between himself and his bride, whether that bride be Israel, Judah or the Church. Our aim here is to examine whether or not the several authors and the two Testaments speak at variance about this matter. It will be shown that in both Testaments God is described as someone who subjects himself to his own law with regard to regulations concerning marriage, separation, divorce and remarriage. He is depicted both by the later prophets and by Paul in ways that are in full accord with the law of Moses.

The area of marriage and divorce is a particularly difficult area for demonstrating consistency between the two testaments, because the traditional Christian teaching is that the Old Testament law is completely at variance with the New Testament law. The law of Moses clearly allows divorce and 
remarriage, but the gospels, as traditionally interpreted, appear to outlaw both. ${ }^{1}$ I would argue that the law did not change, but that Christ affirmed the Old Testament grounds for divorce.

This paper will not explore this issue. The gospels and their interpretation will be deliberately neglected. The subject for this paper is God's own marriage covenants, which are not mentioned in the gospels or in other passages which are adduced by either side of that debate. However, it is expected that an examination of God's own behaviour with regard to marriage and divorce may enlighten those more contentious passages.

I will suggest that Paul and Isaiah $40-55$ are both keen to demonstrate that God fulfils his own law, which was given to Moses, to the letter, even when it appears to be to his disadvantage to do so. It will be shown that scripture declares with one voice that God obeys his own law, and that the law which he obeys remains consistent in both testaments, even in the area of marriage and divorce,

These three marriage covenants will also give us an insight into the significant difference between the Old and the New Testaments. Although God appears to follow the same

${ }^{1}$ For a good survey of traditional church teaching in this area, see $\mathrm{D}$. Smith, 'Divorce and Remarriage from the Early Church to John Wesley', Trinity Journal 11 (1990) 131-42. The Catholic and Anglican teaching has continued to be based on the idea of marriage as an ontological reality which continues until death, even if the couple divorce. They therefore forbid remarriage while both partners live. Most modern Protestant teaching, which allows divorce on the grounds of adultery, is well summarised by J. Murray, Divorce (Philadelphia: Presbyterian and Reformed Publishing Co, 1961). There are many variations based mainly on the interpretation of porneia in Mt. 19:9, which are well summarised in D. Shaner, A Christian View of Divorce (Leiden: Brill, 1969). Some influential modern writers have suggested that even adultery is not a valid ground, and that this concession was made in Matthew only because divorce was compulsory for adultery in Jewish society. This is a contentious point, but it is argued well by $W$. Heth and G. Wenham in Jesus and Divorce (London: Hodder \& Stoughton, 1984). The Jewish background to this debate is covered well by P. Sigal, The Halakah of Jesus of Nazareth according to the Gospel of Matthew (New York/London: University Press of America, 1986) ch. 4, and by C. Keener, '...And Marries Another': Divorce and Remarriage in the Teaching of the New Testament (Peabody, MA: Hendrickson, 1991). 
law, the marriage covenant in the New Testament has significantly better terms than the marriages in the Old.

\section{Old Testament Data}

The covenant with Israel is described in the Pentateuch in terms of a treaty covenant, with the common format of historical prologue, stipulations, divine witnesses and curses on those who break the covenant. We find this pattern in ExodusLeviticus, in Deuteronomy and perhaps in Joshua 24. The only real distinction between these covenants and other extant Ancient Near Eastern covenants is that the witnesses are not a collection of gods but God himself, who is also one of the parties to the covenant. ${ }^{2}$

In the later prophets the theme of God's covenant with Israel continues to be important, but it takes on a different aspect. Now, instead of being a treaty covenant, it is often expressed as a marriage covenant. When each incidence of this kind of language is taken in isolation, one may perhaps regard it as simply an interesting metaphor. But when the different instances are read together, one finds a coherent picture which is maintained by several different authors across several centuries. There is also a great concern of some of these authors that this marriage covenant should conform to all the legal requirements of a marriage covenant in Mosaic law. It appears that the prophets did not regard this concept of God's marriage covenant as an interesting metaphor, but rather they examined it as a legal reality.

The reason why the prophets treated this concept of God's marriage so seriously was probably because they regarded God as the origin of the concept. As far as the prophets were concerned, God himself had declared this marriage to be real in his revelation to Hosea, where he revealed that he was married to both Judah and Israel. This revelation became the inspiration for later prophets who

${ }^{2}$ Another possible difference is that most ANE covenants lacked the blessings which accompanied the curses in OT and Hittite covenants. For a useful summary and bibliography, see J.H. Walton, Ancient Israelite Literature in its Cultural Context (Grand Rapids: Zondervan, 1989) ch. 4. 
reinterpreted Hosea's words and examined them for further insight into God's character and his dealings with his people. ${ }^{3}$

The revelation to Hosea, memorably acted out, contains the bold themes of forgiveness and future reconciliation. Hosea is asked to marry a woman whom he knows will be unfaithful to him, and then to forgive her. In this way, God reveals himself as the victim of an adulterous wife; Israel had pursued other gods and had pursued the help of Assyria.4 Although this adultery is forgiven initially, it then becomes unforgivable. God first supported Israel, his wife, with food and clothing, but she rejected this and looked for support from her lovers instead. Eventually God divorced Israel using the Ancient Near Eastern divorce formula 'You are not my wife and I am not your husband', which is recorded in Hosea 2:2. The result of this is seen visibly because the food and clothing which her husband provided is no longer given and Israel suffers famine and nakedness (2:3-13). Hosea says that God is rejecting Israel, but not Judah (1:4-8). Judah is still married to God. Hosea also speaks of a future hope which includes Israel. Hosea calls that future day 'the day of Jezreel' when Israel and Judah would be united and reconciled to God $(1: 11 ; 2: 14-23)$, and when they would again, together, call God 'my husband' (2:16).

This theme is taken up again in Isaiah 40-55, in Jeremiah and in Ezekiel. After inquiring about Judah's divorce

\footnotetext{
3It has been recognised for some time that OT prophets not only re-used traditional sources in the Pentateuch for their inspiration, but also looked over each other's shoulders and reinterpreted the prophesies of their peers and predecessors. Many examples have been collected by M. Fishbane, Biblical Interpretation in Ancient Israel (Oxford: Clarendon, 1985). This does not imply that this reinterpretation was necessitated by the lack of fulfilment of the original prophesy, a view proposed by R.P. Carroll, When Prophecy Failed: Reactions and responses to failure in the Old Testament prophetic traditions (London: SCM, 1979) 215.

${ }^{4}$ It is not clear whether Israel's lover is portrayed by Hosea as Assyria or the gods which Israel worshipped and the golden calf in particular. References to her prostitution at high places or at threshing floors (4:13; 9:1) suggests that she committed adultery with the gods, but these sites may simply refer to the common sites where prostitutes worked. Assyria is named as the object of her love $(5: 13 ; 8: 9$, remembering that a wild donkey was regarded as a lustful animal, as in Je. 2:24) but Palestinian gods such as the Baals and the calf idol are also named $(2: 13,17 ; 4: 12,17$; $8: 5-6 ; 10: 5 ; 13: 1-2$ ). The frequent mention of her 'lovers' (plural) may suggest that they are all implicated.
} 
certificate (50:1), Isaiah announces: 'Your Maker is your husband', and he is willing to have Judah back (54:5-10). Jeremiah stated that Israel had been unfaithful to her husband (3:20) and asked whether God would have her back after so many adulteries (3:1-5). He described Judah as a youthful bride (2:2) who had copied the adulteries of her sister Israel, who herself had been sent away with a certificate of divorce (3:6-13). Israel was called to return and repent, and was promised a new covenant which would not be based on the ark of the covenant. This would be a time when Judah and Israel would again be united (3:14-18). Ezekiel took up the theme of the two sisters and expanded it (Ezk. 23). He also expanded the idea of the food and clothing which God gave to his bride (Ezk. 16). He speaks about the food and clothing given to Judah, and says that she used it to bribe the nations who were her lovers, and to construct or serve idols who were also her lovers.

The concerns of these later prophets appear to revolve round the details of Jewish marriage covenants. In order to understand the details in these passages, a brief overview of the terms of marriage covenants is needed.

\section{Jewish Marriage Covenants}

We have little data about ancient Jewish marriage covenants, but a great deal can be concluded from Biblical and ancient Jewish sources. Similar marriage covenants are referred to in the Code of Hammurabi, but we will not deal with them here. A marriage covenant was like any other covenant or contract. A contract is an agreement between two parties which benefits both parties and which included penalties in case either party did not keep the terms of the agreement. Covenant terminology with regard to marriage is found in Proverbs 2:17, speaking about the adulterous wife who 'ignored the covenant made before God', and especially in Malachi, who speaks of a 'marriage covenant' (2:14) and says that God is one of the witnesses of that covenant. Malachi, like Jesus, sees the origins of marriage in the act of God who made man and woman from one flesh and united them again as one flesh. Malachi also uses very strong language when he says that God hates divorce (2:16). This poses the problem of how God can hate divorce, and yet divorce his wife Israel. 
The key lies in what Malachi says that God hates. The exact meaning of the words which follow this pronouncement in Malachi is probably impossible to decipher, but one word stands out: BeGaD (בגד), which is usually translated 'treachery'. This word has already been used twice in 2:14-15, where the crime which is condemned is the breaking of a covenant. The word has perhaps been picked up from Jeremiah 3 where Israel's spiritual adultery is called treachery. The word also appears in Malachi 2:11 to describe the action of someone who married the daughter of a foreign God, 5 and in 2.10 where it clearly means the breaking of a covenant: 'why do we profane the covenant of our fathers by acting treacherously with one another'. The sin which God hates, according to Malachi, is breaking the promises made in the marriage covenant. For this reason, the NIV reads: 'you have broken faith with her, though she is your partner, the wife of your marriage covenant.'

God's anger in Malachi was not directed at the innocent woman who was divorced, but at the man who broke the terms of his marriage covenant and divorced her. The man presumably had no proper grounds to divorce her. There was no guilt associated with the divorce itself, but with the breaking of the terms of the marriage covenant. The sin which God hated according to Malachi was the breaking of a promise made as part of a covenant. If the woman had broken her covenant promises to him, he would have had proper grounds for a divorce. The partner who breaks the covenant promises is the one who bears the guilt, not the one who initiates the divorce.

God had proper grounds for divorcing Israel, because she had broken the terms of the marriage covenant by committing adultery. God hates the divorce, because it represents the breaking up of two who should be one. The hateful act is the breaking of promises made before God as

5It is unclear whether Mal. 2:11 refers to the nation of Judah or individuals in Judah who marry 'the daughter of a foreign god'. Malachi swings from speaking about the nation breaking her covenant with God, to illustrations of this in the lives of individuals who have broken their marriage covenants. Usually it is clear which he is addressing at any one point, but in this case it is more difficult. Most probably he is speaking about individuals who have married foreign women, because the nation of Judah would commit adultery 'with a foreign god' and not with 'the daughter of a foreign god'. Whichever it is, the argument in this paper is unaffected. 
witness, as part of the marriage covenant. God does not say that he is angry at the innocent partner who is the victim of those broken promises. After all, God himself was the victim of a broken marriage covenant which he had to end by divorce. 6

When Ezekiel examines God's marriage and divorce, he goes to great lengths to show that God is just and law-abiding in his action. Ezekiel 16 describes in some depth how God fulfilled all the terms of his marriage covenant and how, by contrast, Israel failed to keep these same terms.

The terms of the marriage covenant listed by Ezekiel are the same terms listed in modern Jewish marriage contracts, though the terminology has changed somewhat. These covenant terms stem from the law of Moses in Exodus 21:10-11, which is quoted almost verbatim in some of the oldest marriage contracts surviving.

The best collection of ancient Jewish marriage contracts is found in the Geniza collection in Cambridge, and the best analysis of their content is the study carried out by Mordecai Friedman in 1980.7 He finds Exodus 21:10-11 referred to in several contracts, and alluded to in most of them (1.174-76, 343). 8 The terms of marriage contract which are found in Exodus 21:10-11 are also referred to by biblical authors, as will be shown, and by the early rabbis.

The law of Exodus 21:10-11 concerns the rights of a slave who is married to her master, when her master takes a second wife. The law protects the rights of the slave wife who might otherwise suffer neglect by her husband. He is told that she has three rights which must be maintained: 'he must not deprive her of food, clothing and conjugal rights'. The penalty, if he neglected to continue to provide these three rights, was that 'she is to go free'. It is these final words which form the

${ }^{6}$ For a modern application of this biblical principle, see D. Atkinson, To Have and To Hold: The Marriage Covenant and the Discipline of Divorce (London: Collins, 1979).

${ }^{7}$ M.A. Friedman, Jewish Marriage in Palestine: A Cairo Geniza Study (2 vols.; The Ketubba Traditions of Eretz Israel \& The Ketubba Texts; Jerusalem: Daf-Chen Press, 1980).

${ }^{8}$ References to Exodus 21 were also found in Samaritan marriage contracts. One contract reads: 'He shall not diminish her food, her clothing or her marital rights' (J. Bowman [ed. and trans.], Samaritan Documents Relating to Their History, Religion and Life [Pittsburgh Original Texts and Translations 2; Pittsburgh: Pickwick, 1977] 310, 314). 
basis of Jewish divorce certificates, and these three rights form the basis of the traditional Jewish marriage contract. It was assumed that if a slave wife had these three rights, then a free wife should also have them, and further, that if a woman has these rights, then her husband should also have them. Therefore, from this short text the whole principle of the rights of each marriage partner was inferred as part of the law of God. It was concluded that each partner should find support from the other in terms of food, clothing and love.

It is not clear when these three terms became the basis for the marriage covenant, but they were already well established at the early stages of the development of the Mishnah. A great deal of discussion concerning the exact meaning of these terms fills most of chapter 5 of tractate Ketuvoth. Much of this discussion is late, but it is based on a debate between the Houses of Hillel and Shammai which must be dated in the first century $\mathrm{CE}$. The discussion concern how to interpret the minimum requirement for fulfilling these terms of marriage contract. It was assumed that the man supported his wife by providing money for food and clothing, while the wife supported her husband by purchasing and preparing food and clothing. The exact amount of money and work involved was discussed at length. The frequency of conjugal acts was also discussed, with the Hillelites concluding that a husband may only abstain for one week and the Shammaites that two weeks was permitted. 9

The existence of this debate, and the way it progressed, suggests that these terms of a marriage contract were already part of long-standing tradition by the beginning of the first century.

These terms of the marriage contract are also alluded to in scripture, in the Old and New Testaments, especially in Ezekiel and Ephesians, though also less explicitly in other passages.

One interesting example occurs in Psalm 132, which is a beautiful version of the promises of God made to Jerusalem. These promises are made in terms of a marriage covenant, based on love. The Lord says in verses 13 and 14 that he

${ }^{9} \mathrm{~m}$. Ketuvah 5:6 
'desires' 10 Jerusalem, and that he will 'clothe' her priests, and that he will 'satisfy her poor with food'. These references to food, clothing and love are reflections of these three terms of a marriage covenant, which God says that he will provide for his bride.

\section{God's Divorce from Israel}

Ezekiel in particular examined God's covenant with Israel and listed in detail the way in which God fulfilled the terms of the marriage contract. He listed the way in which he fulfilled these terms, not in a niggardly way, providing only what was necessary, but in abundance. He described how God first met his love, when he found her in the wilderness as an abandoned baby (16:1-7) and how he cared for her while she grew up. When she was ready, he wooed her and entered into a marriage covenant with her: 'I spread the corner of my garment over you...I gave you my solemn oath and entered into a covenant with you' (16:8). Having declared and consummated his love, he provided her with clothing and food, the other two terms of the marriage covenant. The clothing and food he gave her was far beyond that necessitated by their covenant. He gave her the very best luxuries: 'I clothed you with an embroidered dress and put leather sandals on you. I dressed you in fine linen and covered you with costly garments' (16:10), and 'Your food was fine flour, honey and olive oil' (16:13). This is an expansion of a similar theme of Hosea who says that God gave her food and clothes (2:3-13).

The three obligations, to provide food, clothing and love, were faithfully fulfilled by God towards Israel, but they were not reciprocated. Ezekiel says that instead of using the costly cloth which God had provided to make garments for them both, she used them to clothe the idols who were her lovers (16:16-18) and instead of preparing the food which God had provided to make meals for them to eat together, she offered it up as food offerings to these idols (16:19). She also withheld her love from God, thus breaking the third term of her marriage covenant. Then she broke the last term of her marriage covenant, the promise of faithfulness, by committing adultery with the idols.

אוה10, 'to desire', is used of physical desires including sexual desire; $c f$. Ps. 45:11(12); Je. 2:24. 
The conclusion of Ezekiel's deliberations is that God was perfectly justified and acting within the law when he divorced Israel.

Divorce was perfectly lawful within the law of God.11 Divorce is specifically referred to in Deuteronomy 24:1-2 as the proper remedy when one's partner was unfaithful. This ground for divorce could only be applied to women, because the permissibility of polygamy meant that adultery by a man could not be a ground for divorce. A woman was assumed to promise to be faithful to one man when she married him, but a man could not be assumed to make the same promise as part of the marriage contract, because it was permissible for him to take more than one wife. Although polygamy never appears to have been common, the possibility of polygamy meant that an adulterous man could not be said to have broken a term of his marriage contract. It was recognised that he had sinned, but this sin did not involve breaking his marriage contract. The woman on the other hand had broken her marriage contract, and could therefore be divorced for committing adultery. 12

The possibility of divorce is also implied in Exodus 21:10-11, when it says that the slave wife who has been wronged must be 'set free'. Rabbinic discussions about divorce are often based on these words. They said that a divorce

11 This is not to say that divorce was looked on lightly (see on Malachi above), but the present author does not go as far as A. Cornes in Divorce and Remarriage: Biblical Principles and Pastoral Practice (London: Hodder \& Stoughton, 1993). Cornes understands Mal. 2:16 to mean that God condemns all divorce. In speaking about God's own divorce, Cornes tries to argue that this was only a temporary separation.

12In rabbinic times it was considered necessary for a man to divorce an adulteress; see m.Yebamoth 2:8, m.Sotah 5:1 and other references in L. Epstein, The Jewish Marriage Contract: A Study in the Status of the Woman in Jewish Law (New York, 1927) 210-11. M. Bockmuehl gives yet more Jewish sources and the most important Roman ones ('Matthew 5:32, 19:9 in the Light of Pre-Rabbinic Halakhah', NTS 35 [1989] 291-95, 292). However, this was never part of the Law in Scripture. The Law says that a suspected adulteress should be subjected to the rite of Bitter Water as prescribed in Numbers 5. This may be what Hosea hints at in 2:3 where he says: 'I will strip her naked.' Although Numbers merely says that the priest humiliates the woman by loosing her hair, the rabbis assumed that this was a euphemism for stripping her to the waist, although the pragmatic rabbis noted that this part of the humiliation should be omitted if the woman was comely (m.Sot. 1:5). 
certificate was similar in many ways to a certificate of freedom for a slave, ${ }^{13}$ and the only words which the rabbis decided were absolutely necessary on a divorce certificate are a reference to this text: 'You are free to marry any man'. These words were enough to fulfil the purpose of a divorce certificate, which was to prove that the woman was eligible for remarriage because she was no longer any man's wife. Only the woman got a divorce certificate, because the man could marry more than one wife and therefore did not need any proof that he was divorced.

The rights of the slave wife in Exodus 21 were applied to free wives and also to men. Along with the rights to these three types of support went the right to a divorce if any of these three terms of the contract were broken. It was the right of a slave wife to be set free if she was neglected emotionally or physically, so this was the right of all married people.

It is often assumed that women could not divorce men. Technically this was true, in that only men could write out a certificate of divorce. Also adultery was not a ground for divorce against men. In practice, however, Jewish women could and did divorce their husband, on the grounds of not fulfilling the terms of Exodus 21:10-11. If they had proper grounds for a divorce, the rabbinic court would force the husband to write out a divorce certificate, by fining him a set amount every day that he refused. Although no records survive of individual Jewish women who got a divorce in this way, this is not really an objection, because neither are there any records of Jewish

${ }^{13} \mathrm{~m}$.Gittin 9:3: 'The essential formula in the bill of divorce is: "Lo, you are free to marry any man"...The essential formula in a writ of emancipation [from slavery] is: "Lo you are a freedwoman: Lo you belong to yourself"'. m.Gittin 1:4-6 and m.Mama Metzia 1:7 also lists several ways in which a certificate of divorce is similar to a certificate of emancipation from slavery. This wording of m.Gittin 9:3 is at least as old as the Pauline corpus, because it is quoted in 1 Cor. 7:39. Paul quotes it with regard to a widow, who shared with a divorcee the privilege of being able to marry whomever she wishes. When they were married the first time they were bound by the wishes of their father or family. The second time round they have complete freedom. Whether or not Paul regards that divorcees could remarry is still a matter of debate, but widows could. However, as is common in the Corinthian correspondence, Paul adds a rider to the quotation-'only in the Lord'. He tells them that although widows have complete freedom, they should only choose to marry a fellow Christian. 
men who divorced their wives. There are, however, early Mishnaic texts which contain the results of extensive discussions about the amount of money the husband should be fined, and the exact limits which constituted a breach of contract. ${ }^{14}$ Before Mishnaic times there is also evidence that women divorced their husbands in the remarkable documents preserved from the Elephantine Jewish community of the fifth century BCE. 15

Divorce is part of God's law for a fallen humanity, because of our 'hardness of heart', according to Jesus (Mt. 19:8). Jesus and Malachi emphasised that this was never part of God's ideal, and that it is a result of sinfulness. However the sinfulness does not lie in the process of divorce itself but in the breaking of the marriage covenant. As Ezekiel showed, Israel broke her marriage covenant vows while God kept them to the letter and far beyond, so God was righteous in divorcing her.

\section{God's Reconciliation to Judah}

Jeremiah and Isaiah were just as concerned as Ezekiel to show that God kept his own law with regard to marriage covenants. However they were more concerned with Judah than Israel.

Hosea had stated quite clearly that God would divorce Israel, but that the covenant with Judah would continue to the end of time. By the time of later Isaiah and Jeremiah it was clear that Judah had also been sent into exile, so it appeared that she too had been divorced by her husband. If the prophesy in Hosea was correct, it would either have to be shown that Judah had never been divorced, or God would have to remarry Judah. 16

\footnotetext{
${ }^{14} \mathrm{~m}$. Ket. 5:7-9.

${ }^{15}$ A.E. Cowley, Aramaic Papyri of the Fifth Century BC (Oxford: Clarendon, 1923). E.G. Kraeling, The Brooklyn Museum Aramaic Papyri (New Haven: Yale UP, 1953). Example 15 in Cowley and examples 2 and 7 in Kraeling are marriage documents which include the grounds and procedure for divorce. It is clearly stated that the woman or the man can demand a divorce in the Assembly.

16Hosea did not see this problem because he did not know about the exile of Judah. As far as he was concerned the marriage with Judah simply carried on for ever. Israel's renewal of the covenant (1:11) did not need a remarriage, because it would happen when Israel and Judah were reunited.
} 
Remarriage after divorce was possible within the law. Deuteronomy 24:1-2 specifically showed that a person may remarry, and even implied that this is true for the guilty as well as the innocent partner. Deuteronomy 24:1 is a piece of case law from which a large amount of general law has been generated. It referred to a very specific situation where a woman had been divorced for some kind of sexual transgression (literally a 'matter of nakedness'), remarried, divorced again, and then wanted to remarry her first husband. The ruling is that she may not remarry her first husband. Out of this case law came the general laws about writing divorce certificates and about sexual misconduct as a ground for divorce. The very specific situation where a woman wanted to remarry her former husband also became a general prohibition.

This means that God would be breaking his own law if he remarried Judah, who had formerly been divorced by him. In fact Judah appeared to fit the situation described in Deuteronomy 24:1-2 almost exactly. She had been divorced because of her adultery, and then she had gone off presumably to marry one of her lovers such as Syria, from whom she hoped to have protection from the Babylonians. When she had been rejected by Syria, she wanted to come back to her first husband. The law of Deuteronomy 24 clearly forbade this.

Jeremiah poses exactly this problem in 3:1: 'If a man divorces his wife and she leaves him and marries another man, should he return to her again?', and he applies this to Judah: 'You have lived as a prostitute with many lovers; would you now return to me?'. This is a direct allusion to Deuteronomy 24:1-4 which forbids this precisely. Jeremiah is clearly concerned by this, but appears not to come to any solution. He proclaims the fact that there will be a new covenant, which is not based on the ark of the covenant (3:16) and perhaps he thinks that this new covenant will not be subject to the law of Moses.

Isaiah looks into the problem further, and examines it in a different direction. Instead of trying to discover how God can remarry Judah without breaking the law, he looks into the possibility that Judah was never divorced at all.

It is clear that Israel was divorced by God. Jeremiah, in an early prophecy refers to her certificate of divorce (Je. 3:8). A divorce certificate must be written, since Deuteronomy 24:1 
says that the man 'writes a certificate of divorce'. The written divorce certificate which Jeremiah refers to is presumably the written record of Hosea 2:2: 'She is not my wife and I am not her husband'. This is the written version of an ancient Near Eastern verbal formula for divorce. This formula is found in the Jewish Elephantine divorce certificates of the fifth century BCE and in older sources from other cultures. Geller, 17 who has collected the ancient instances of this formula, regards it as equivalent to the later Jewish formula 'I release you' or 'I repudiate you'.

Isaiah looked for evidence that Judah had been divorced like Israel. He concludes that she had not, because there is no divorce certificate. He asks rhetorically in Isaiah 50:1: 'Where is your mother's certificate of divorce with which I sent her away?'. He explains in Isaiah 54 that God did not divorce Judah, like he divorced Israel, but he only separated from her for a while before seeking her again. He calls Judah 'a wife deserted' says 'for a brief moment I abandoned you' (Is. 54:6-7).

Isaiah, like Jeremiah, presumably found Israel's certificate of divorce in the words of Hosea 2:2. Israel was, according to Hosea, well and truly divorced. But Isaiah points out that Judah has no such certificate of divorce. It was inconceivable that a divorced woman or her children would not know where her certificate of divorce was. This was her most precious document, because it allowed her to remarry, and often carried financial details of her inheritance. If there was no certificate of divorce, there was no divorce.

Isaiah concluded that if Judah was not divorced, then the exile, which was coming to an end, was merely a time of separation. There was therefore no legal problem if Judah and God were reunited, because this would not be a remarriage but a reconciliation.

\section{God's Multiple Wives}

None of the prophets questioned the fact that God was married to two wives at once, though they all recognise the fact. Hosea says that God would no longer show love to Israel, but he would continue to love Judah (1:6-7), while Jeremiah and

${ }^{17}$ M.J. Geller, 'The Elephantine Papyri and Hosea 2:3; Evidence for the Form of the Early Jewish Divorce Writ', JSJ 8 (1977) 139-48. 
Ezekiel plainly speak about God being married to two sisters, Israel and Judah (Je. 3:7-11; Ezk. 23). This does not present a problem to the prophets because polygamy was allowed for in the law of Moses.

Jesus indicates that this was not the original intention of God when he quotes 'the two will become one flesh' (Mt. 19:5; Mk. 10:8). This is a reworking of Genesis 2:24, which reads simply 'and they become one flesh'. The word 'two' does not occur in the Hebrew text, though it was traditionally added to the passage, as seen in the Septuagint, the Targums, and even in the Samaritan traditions. ${ }^{18}$ In this way, Jesus was aligning himself with the growing body of Jews who recognised that monogamy was God's ideal.

It could be argued that God was in fact a monogamist. The marriage covenant of God with Israel and Judah could be traced back to Mount Sinai before Israel and Judah became distinct entities. This would mean that God only married one wife. Hosea and Jeremiah specifically trace the marriage back to the days when Israel came out of Egypt (Ho. 2:15; Je. 2:2), while Ezekiel traces it back to the days of their emergence in Canaan (Ezk. 16:3). It could also be pointed out that the eschatological vision of the prophets was that Israel and Judah would once more be united as a single nation in the new marriage covenant (Ho. 1:11; Je. 3:18; Ezk. 37:15-6). Therefore he would again be married to only one wife. In this matter too, God follows the letter of his own law, though he works towards the spirit of it. He is able to be married to two wives, but he seeks to reunite Israel and Judah so that he will be married to only one.

\section{Summary of the Old Testament Data}

The Old Testament data, taken from a wide range of authors, shows a consistent and coherent picture. The laws of marriage and divorce in the books of Moses were applied by the prophets to the marriage covenant of God with Israel and Judah. The revelation to Hosea was examined and re-evaluated by Jeremiah, Ezekiel and Isaiah. They all concluded that Israel was divorced, and deservedly so because she broke the terms of the marriage covenant. Judah also committed adultery, and she appeared to be divorced when she was exiled. However,

18Bowman, Samaritan Documents, 310; J. Jeremias, Jerusalem in the Time of Jesus (London: SCM, 1969) 369. 
there was never any formal divorce certificate, so Isaiah concluded that she only suffered a temporary separation. This means that she could be lawfully wooed by God again.

\section{New Testament Data}

The prophets also spoke about a new marriage covenant in the future, with much more favourable terms. Jeremiah and Ezekiel specifically call it a new covenant. What they do not explain is how a wife can end one marriage covenant and start another with the same husband without contravening the law. This problem was left for Paul to solve.

This new covenant presented both a wonderful promise and two new problems for Paul. The first problem was how the gentiles could join a covenant which was essentially Jewish. The second was how the Jews could end their old marriage covenant in order to take part in the new and better one.

Paul's solution to his first problem is in fact the origin of his second problem. He solves the matter of the gentiles by pointing to the absolute newness of the new covenant. This new covenant is not based on the law, in the way that the old covenant was. This is not to say that the law is denied or broken, because the seeds of the new covenant are in the old covenant. The Prophets spoke of this new covenant, and specifically stated that the gentiles were welcomed into it. Therefore the very existence of the new covenant required the writings of the old covenant to substantiate and legitimise it.

Paul clearly saw a link between the old and new covenants, in that both are based on a marriage covenant, and both are subject to the law of Moses. He also saw a great difference between the two covenants in that the terms of the new covenant seem to be much more favourable for the Bride of Christ than they were for Israel and Judah. Paul's main exposition of his understanding of the Bride of Christ occurs in Ephesians; even if this letter is not by Paul, it does at least reflects his theology.

\section{Excursus on Submission}

Any examination of the terms of marriage in the New Testament is liable to be diverted by the subject of submission. It would appear from some texts that a wife should be in total 
submission to her husband as one of the terms of the marriage contract, and that this model applies equally to the marriage of Christ and the church and to human marriages. Although submission is an attractive concept in worship, it might have different, sometimes tragic, consequences when the one to whom submission is given is a fallible and perhaps even a vindictive human. Before continuing to examine the improved terms of the New Testament marriage covenant with the Church, this spectre of 'submission' must be examined.

Ephesians 5-6 contains a series of moral exhortations under the general heading 'submit to one another' (5:21). Colossians 3-4, Titus 2-3 and 1 Peter 2-3 follow the same order and wording, and when the wider context is taken into account, there are also parallels with James 1 and 4. This led P. Carrington, D. Daube and subsequent scholars to conclude that these passages are based on an underlying Christian catechism or (more likely) a Jewish or pagan moral code. A most significant addition to this common material is found in Ephesians where the phrase 'wives, submit to your husbands' is expounded by comparing human marriage to the marriage of Christ to his church.

The subject of the submission of wives cannot be alluded to without explanation in our society. Similarly in the New Testament, Christian writers felt constrained to explain why wives should submit; in every place the teaching occurs it is accompanied by some kind of explanation. This may suggest that the New Testament writers felt the same kind of unease and defensiveness about this teaching as many do today.

In Ephesians, this phrase about submission of wives is expounded and partly explained as an analogy of the church's relationship to Christ. The force of this command is also deliberately weakened by preceding the passage with the phrase 'submit to one another out of respect for Christ', which is expounded as a series of ways in which each Christian, male and female, slave and free, can submit to others as they would to Christ. The teaching about wives submitting is further qualified by concluding the passage with the phrase 'the wife must respect her husband', so that the force of the word 'submit' turns into 'respect'.

In 1 Peter the phrase 'wives submit' is interpreted differently, as a means by which an unbelieving spouse may be 
converted (1 Pet. 3:1-6). This implies that submission is not perceived as a means of fulfilling a marriage contract but as a means of impressing one's husband by going beyond what is necessary. This is similar to the explanation given in Titus 2:5. Both passages appear to teach that Christian wives should keep the ideal standards which pagans regard to be moral, so that the gospel will spread. Therefore, according to 1 Peter and Titus, Christian wives should submit for the sake of the gospel, and not because it is part of their marriage contract.

It appears that Christian writers put forward a common moral code which included one aspect which many were not too happy about: this teaching that wives should be submissive. They therefore added reasons why Christian wives should be ruled by this aspect of the moral code. There was another part of this moral code which they also appeared to be unhappy about: that slaves should submit to their masters. They treated this in a similar way to the submission of wives. It is expounded in Ephesians as an analogy to our relationship with Christ (Eph. 6:5-8), and in 1 Peter and Titus as an expedient in order that the gospel will not be slandered (Tit. 2:9-10); 1 Peter adds that Christ is our example as the suffering servant.

Submission was not part of the new Christian morality, as anyone at the church of Corinth knew too well. Neither was submission part of a Jewish marriage covenant. Marriage was not forced on a Jewish girl, even if it had been arranged by her parents. A necessary part of a marriage covenant was an indication that the wife had agreed to the marriage. There was also an implied limitation to the concept of submission in the three rights in the marriage covenant, for food, clothing and love.

Submission of wives was part of Christian teaching because it was part of the ideal morals of Roman society. It could be argued that this aspect of morality was a nostalgic reverence for the laws of Augustus, which were imposed after a revolt of high-society women who complained against a new tax on rich women. Augustus introduced a whole series of laws restricting the freedom of women, which never really worked, but which, in hindsight, probably became confused with the ideals of Athenian society in which women played no role at 
all.19 These laws were largely disregarded, but some of them were occasionally appealed to. If Christians were going to overcome the natural mistrust of Roman society, they could do no better than follow a strict, culturally acceptable moral code. This, therefore, was the moral code which was taught to all Christians, including the submission of wives to husbands and slaves to masters, so that they would be regarded as righteous even by the pagan society they attempted to convert to the freedom of the gospel.

\section{God's Marriage to the Church}

Ephesians teaches submission of the wife to her husband, but does not emphasise it, even with regard to the submission of the church to Christ. What is emphasised in this passage is not the responsibilities or duties of the Bride of Christ, but the benefits which Christ gives to his bride. He loves her even to the point of dying for her, then cleanses her in the water of the word, and he feeds and clothes her. The three rights established in a marriage covenant are clearly named here: love, food and clothing. Love is emphasised, but food and clothing are also specifically mentioned in 5:29: 'feeds and keeps warm'

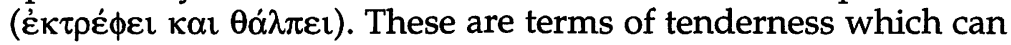
be translated in the less practical phrase 'to nourish and cherish' $^{\prime 20}$ the first meaning to nurture into maturity as much as to feed, and the second meaning to embrace as much as to keep warm. ${ }^{21}$ This tendency to replace the stark terms of Exodus 21, of food, clothing and sexual relations, with more tender and euphemistic terms such as 'love, cherish and keep' is well attested in Jewish marriage contracts. M.A. Friedman lists terms such as 'nourish' 'provide for', 'honour' and 'esteem'. Only diaspora documents mention conjugal rights, using the wording 'I am obligated to provide your food, clothing and

\footnotetext{
${ }^{19}$ For a useful overview, see M. Grant, Greeks and Romans: A Social History (London: Weidenfeld and Nicolson, 1992) 32ff.

${ }^{20} \mathrm{This}$ is the wording in the AV. It is very close to the wording of traditional Christian wedding services, which suggests that Christian wedding vows are descended from Ex. 21:10-11, as are those in Jewish marriage contracts; see 'Ketubah' by 'JHG' in I. Singer (ed.), Jewish Encyclopedia (12 vols.; New York/London: Funk \& Wagnalls, 1905) 7.472.

${ }^{21}$ See especially the LXX use of $\theta \dot{\alpha} \lambda \pi \omega$ at Dt. 22:6; Jos. 39:14; $1 \mathrm{Ki} .1: 2,4$. However, the practical import of these terms has been recognised as long ago as Bengel's Gnomon, ad loc.
} 
needs and to come to you as the way of all the world.' The last phrase is a euphemism for sexual relations, and this was usually omitted.22

The reference to Christ 'washing' his bride is particularly significant. Many commentators have suggested that this refers to a prenuptial bath, as it undoubtedly does, but no groom would ever have been the bath attendant to his bride. In terms of scriptural allusions, this probably refers back to Ezekiel 36:25, 'I will sprinkle you with clean water'; this was to cleanse Israel from their sins of idolatry and to make them ready for the new covenant. ${ }^{23}$ In terms of the typical Jewish marriage covenant, however, it takes on a completely new aspect, reflecting some of the wording in the traditional marriage contract in the section associated with the three rights of food, clothing and love. Here the bride promises to be like other Jewish brides who 'esteem, honour, attend and serve their husbands in purity and cleanness'. ${ }^{24}$ The wording in Jewish marriage documents varies, but some portions are well established by tradition so that they vary only slightly. This phrase comes from a traditional section of the contract, which is virtually the same in every ancient contract which has been preserved in the Geniza, suggesting that the phrase is very old.

The phrase 'in purity and cleanness' is significant because only the bride has to promise this. ${ }^{25}$ The groom promises to 'nourish, sustain, provide for, clothe and honour you, in the manner of Jewish men who nourish, sustain, provide for, clothe and honour their wives faithfully'. There is no reference here to submission, nor any promise to maintain purity or cleanliness. In other words, the bride only, but not the groom, promises two things: to submit, and to be pure and clean.

The significance in Ephesians is that Christ gives this purity to the bride. The bride, his church, is not requested to present herself or even keep herself pure, but instead the

${ }^{22}$ Friedman, 1.19, 169-78.

${ }^{23}$ The rabbis regarded the 'water' here as representing the Torah; see references in C.G. Montefiore and H. Loewe, A Rabbinic Anthology (New York: Schocken Books, 1974) 164-65.

24This is example number 11 from Friedman's collection of the Geniza marriage contracts (2:131ff.), but there are many other similar examples.

${ }^{25}$ This phrase is a reference to the laws of menstrual purity which do not apply to the man. 
bridegroom, Christ, offers to give her purity and cleanliness. Looking at Ephesians in this light, it becomes clear that the whole passage emphasises things which Christ will do for his church (love her, clothe her, feed her, and make her pure), but we hear nothing that the church has to do in return, except submit. There is no reference to the bride carrying out her duties in preparing food and clothing, or even to keep herself pure. This is a very strange marriage covenant, because it is completely one-sided in favour of the bride. The groom makes all the promises, and the bride gets all the benefits. It is in this one-sidedness that the difference between the old covenant and the new covenant lies.

\section{Old and New Covenants Contrasted}

The Old Testament prophets characterised the new covenant as one which is written on hearts, not on stone. This is the theme in Ezekiel 36:26-27, just after the verse about cleansing which was cited in Ephesians. This theme of a new covenant written in the heart is also found in Jeremiah 3 and 31, Ezekiel 16, Isaiah 54 and Hosea 2, as well as other places. All the references listed here occur in the context of God's marital problems with Judah and Israel.

The main difference between the old and new covenants, as highlighted by the prophets, is that the new covenant is no longer based on a written code. Jeremiah says that the Ark of the covenant, which housed the stone tablets, will no longer be important (Je. 3:16), and later says, 'they broke my covenant, though I was a husband to them' and 'this is the covenant I will make...I will put the law in their minds and write it in their hearts' (31:32-33). Ezekiel takes the imagery further and says that, just as the law used to be written on stone, so too the people used to have stone hearts, but 'I will remove your heart of stone, and give you a heart of flesh, and I will put my Spirit in you' (36:26).

Ephesians applies this revelation about the new covenant in the terms of a marriage covenant. It is no longer based on a written document containing terms or laws which have to be kept. All the promises are made by Christ, to love, feed, and clothe his bride. The bride is not asked to make any such promises. Even the additional burden of a Jewish bride, to keep herself clean and pure, is taken up by Christ on behalf of 
his bride. The written law becomes a voluntary guideline which is submitted to out of love.

\section{Entrance of Jews into the New Covenant}

This is a wonderful promise, and yet also a terrible problem for those who are joined to God in the old covenant. Paul was keen for Jews and gentiles to join together in the new covenant, as the prophets envisioned, but how could a bride have two marriage covenants? A man could have two wives, but a wife could only have one husband, and one marriage covenant. Even if she divorced her husband, a remarriage to her same husband would be regarded like a reconciliation, with a renewal of her original marriage covenant. If she married and divorced someone else, and then tried to remarry her first husband with a new marriage contract, she would be barred from remarriage by the law of Deuteronomy 24:1-2, which forbids remarrying one's former husband. It therefore seems impossible that Jews could take part in the new covenant, because they could not end their present marriage covenant and start up a new one with the same husband.

Paul must have been tempted to say that the analogy of a marriage covenant breaks down at this point. However, like the prophets, he regarded it as more than an analogy. This marriage of God to Israel was a solemn binding covenant which could not simply be disregarded. He struggled with the problem, and eventually found a solution. If the Jews could not end their old covenant by divorce, then the only other way to end a marriage covenant was by death. Paul pointed out that just as Christ had died, so too had his disciples died 'in Christ', so that the old marriage covenant ended with death.

Paul presented this conclusion in an extended illustration in Romans 7:1-4. He pictured a woman married to a perfect, though dour man (the old law). The woman would rather be married to a more attractive and easygoing man (the new law). It is needless to say that she cannot divorce her husband because she has no grounds for a divorce. She knows that he will never break any of the marriage vows, and so she will never be able to divorce him, and he does not want to divorce her. She considers going to live with the more attractive man, but that would be adultery. Her only possible course of action is to wait for her husband to die. Paul concludes 'you 
died to the law through the body of Christ, that you might belong to another' (7:4).

Paul concluded that the old marriage covenant ended with death, that is, with the death of Christ, in whom the marriage partner also died. This meant that the Jews were now free to marry another, who actually was the same-the resurrected Christ. 26

The gentiles were also able to become part of the Bride of Christ by joining this same covenant. Paul finds proof of this in the same prophesy of Hosea where the concept of God's marriage covenants began. In Romans 9, Paul looks for proof that the gentiles and the Jews will join together in a single covenant, and finds it in Hosea 2:23: 'I will show love to "Not my beloved" and I will say to "Not my People" "You are my people"'. In the original context, this speaks about Israel who was divorced and who would be reunited with God when she is reunited with Judah. Paul's exegesis is presumably based on unpacking the parallelism so that 'Not my Beloved' refers to Israel and 'Not my People' refers to the gentiles. ${ }^{27} \mathrm{He}$ can thereby argue that this text shows the gentiles as well as Israel joining Judah in a single marriage covenant. He indicates that this is his exegetical method by reversing the order of the phrases so that 'Not my People' is named first, which suggests that this is the phrase he is depending on to prove that the gentiles will be joined to the covenant.

In this way, Paul demonstrates that both the Jews and the gentiles are able to share the new marriage covenant of the bride of Church with Christ without breaking the spirit or the letter of the law.

\footnotetext{
${ }^{26}$ Catholics and others who believe in marriage as an ontological reality which can only be ended by death use this text as a proof that death is the only way that a marriage can end. For a good summary of the history of this interpretation, see V.N. Olsen, The New Testament Logia on Divorce: A Study of their Interpretation from Erasmus to Milton (Tübingen: J.C.B. Mohr [Paul Siebeck], 1971). This fails to take into account the context of the passage, which is speaking not about a normal marriage but about a new covenant relationship with Christ.
} 


\section{Conclusions}

This survey of the marriage covenants of God with Judah, Israel and the Church, found that scripture in both Testaments presents God as one who consistently follows his own law. The two covenants do not present two Gods or two laws, or even a God who has changed the way that he acts towards humanity. What has changed in the New Testament is the requirements which are made of humanity. Humanity is no longer required to reciprocate the promises which God has made.

In the old covenant, which was presented as a treaty covenant in the Pentateuch and as a marriage covenant in the Prophets, both sides made promises, and both sides were required to keep those promises. As a result of their failure, Israel's covenant was ended, and in the view of the Prophets this resulted in divorce. Judah, for some reason, was treated less harshly, though she too was cut off from God for a time before God initiated reconciliation. The new covenant is also described as a marriage covenant, but a very strange one, in which the bride does not appear to have any promises to keep. All the promises are made to and for the bride by Christ, who not only died for her, but who requires nothing more than her submission to him.

God is portrayed as one who keeps the law meticulously, to the letter. The law of Exodus 21:10-11 says the husband must provide food, clothing and love for his wife, and Ezekiel 16 lists the way in which God fulfilled each requirement. The law of Deuteronomy 24:1-2 forbade the remarriage of a woman to a former husband, and Isaiah discovers that Judah was not remarried to God because she was never actually divorced. This same law made it impossible for the Jews to share the benefits of the new marriage covenant, but Paul points out that the law was fulfilled by Christ's death, by which the old covenant was ended.

God has been seen to have the same character in both Testaments. Both the Prophets and Paul are concerned to show that God restricts himself to his own law. The establishment of a new covenant does not imply a new law. Paul and the gospel writers are keen to show that Christ did not abolish the law, but fulfilled it. The marriage covenant of Christ and the Lamb is based on the law, and fulfils it to the smallest detail, and yet none of the burden of that law falls on the bride, the Church. 
The new covenant is therefore an excellent example of the principle that the two Testaments of the Bible speak with a united voice about a single consistent God who subjects himself to his own single and unchanging law. 